PRELIMINARY EVALUATION OF THE IMPACT

\title{
OF ANTIOXIDANTS POLYVINYLPYRROLIDONE AND ASCORBIC ACID ON PATCH BUDDING OF PERSIAN WALNUT
}

\author{
Ahmadreza ABBASIFAR*, Babak VALIZADEHKAJI \\ Faculty of Agriculture and Natural Resources, Arak University \\ 38156-8-8349 Arak, Iran
}

Received: August 2017; Accepted: November 2017

\begin{abstract}
The purpose of this study is to investigate the effect of antioxidants on the budding success of three walnut genotypes under greenhouse conditions. After stratification, seeds were planted in a greenhouse at the end of autumn. After about 20 months, the seedlings grew up to $80 \mathrm{~cm}$. The budding was done using scions of Z30, Z60, and B21 genotypes. Scions were immersed in polyvinylpyrrolidone (PVP) or ascorbic acid in the concentrations 2,3 , and $4 \mathrm{~g} \cdot \mathrm{dm}^{-3}$ for $1 \mathrm{~h}$ before budding. Percentage of successful budding was determined after one month. The results showed that genotype significantly affected the percentage of budding success, but no interaction between genotype and treatments was found. The antioxidant solutions significantly affected all the parameters studied in this research. Ascorbic acid with $3 \mathrm{~g} \cdot \mathrm{dm}^{-3}$ resulted in the highest percentage of budding success $(86.66 \%)$; no significant differences were observed with $4 \mathrm{~g} \cdot \mathrm{dm}^{-3} \mathrm{of}$ ascorbic acid and 3 and $4 \mathrm{~g} \cdot \mathrm{dm}^{-3}$ of PVP. Furthermore, antioxidant solutions significantly affected the content of chlorophylls, and $3 \mathrm{~g} \cdot \mathrm{dm}^{-3}$ of ascorbic acid resulted in the highest content of chlorophylls in scion leaves.
\end{abstract}

Key words: walnut, patch budding, cultivar, antioxidant, budding success

\section{INTRODUCTION}

Walnut is one of the most important nut fruit trees in many parts of the world and has long been considered by humans to produce fruit and wood. Iran produces 445,000 tons of walnuts what places it on the second place in the world, after China (FAO 2014). However, the export of walnuts in sizable amount needs the evenness of the product in terms of size, quality, and other apparent traits and this production should be based on clonally propagated best genotypes (Godeanu et al. 2004). This kind of vegetative propagation uses grafting or budding. Among budding techniques, patch budding is the most common and most successful for walnuts in most walnut producing countries in the world (Kasmi et al. 2013; Pinghai \& Rongting 1993). Although propagation of walnut by budding is possible, it has lower efficiency compared to most fruit trees what increases the price of grafted seedlings. The important reason for low budding success in walnuts is the high phenolic content in this plant. In the wound caused by budding, these compounds are oxidized by phenol oxidases and molecular oxygen and turned into complex of molecules that are brown or dark what results in necrosis of the tissues at the site of the budding (Karadeniz 2005). It should be noted that the percentage of budding success among different cultivars and genotypes is significantly different probably also because of differences in their phenolic materials content (Rezaee \& Vahdati 2008; Vahdati \& Zareie 2005; Karadeniz 2005). There are reports on the effect of high concentrations of phenolic substances on budding and grafting success (Mng'omba et al. 2008; Azimi et al. 2016). Karadeniz (2003) reported that there is a negative correlation between the amount of phenol and the percentage of graft success in the walnut. Reddy 
and Melanta (1989) and Karadeniz (2003) stated that grafting success was associated with phenolic content of scion. In apricot, the accumulation of some phenolic compounds at the site of budding union leads to a lack of differentiation of callus and various intracellular disorders (Errea et al. 1994 a, b). Generally, phenols lead to minimization of cells and lack of grafting success (Errea et al. 2001). In addition, some phenols influence the success of grafting by affecting the amount of auxins, which play a role in the growth and development of cells and induction of differentiation of vascular tissues in the graft site (Aloni 2001). The monophenol (p-coumaric acid), by increasing the activity of indoleacetic acid (IAA) oxidase, decomposes the auxins (Lockard \& Schneider 1981). In the cherry graft on the sour cherry, the accumulation of prunin was seen above the grafting site. A flavanone prunin increases the oxidative degradation of IAA and is proposed as a marker of incompatibility between graft components (Treutter \& Feucht 1988).

Zakinthinos and Rouskas (1997) and Alzate et al. (2002) have shown that one of the methods to enhance grafting success in plants with high phenol is the use of various antioxidants - such as polyvinylpyrrolidone (PVP), ascorbic acid, or citric acid to reduce the oxidation of phenolic substances in the site of the graft. So far, no report has been published on the effect of scion immersion in antioxidant solutions on the effectiveness and percentage of patch budding.

Therefore, the purpose of this study is to investigate the effects of scions immersion in antioxidants PVP and ascorbic acid solutions at various concentrations on the budding success rate of three superior genotypes of walnut $-\mathrm{Z} 30, \mathrm{Z} 60$, and B21.

\section{MATERIALS AND METHODS}

The seeds of the rootstock were harvested from a tree and then stratified for about eight weeks at a temperature of $4-5{ }^{\circ} \mathrm{C}$ in a wet perlite after disinfecting it with fungicide. Subsequently, the seeds were planted in late autumn in a greenhouse in planting beds containing one-third soil, one-third decayed manure, and one-third wind sand with a distance of $20 \mathrm{~cm}$ in the row and $50 \mathrm{~cm}$ between the rows. After about 20 months when seedlings were approximately $80 \mathrm{~cm}$ high, patch budding was performed at the beginning of July.

Factorial experiment was conducted in a completely randomized design with 3 superior genotypes - Z30, Z60, and B21 - as the first factor and PVP and ascorbic acid in concentrations 2,3 , and $4 \mathrm{~g} \cdot \mathrm{dm}^{-3}$ plus water in the control as the second factor, in 5 replicates and at least 10 seedlings per replicate. The scions were prepared from strong 1-year branches and were used for budding after immersion for $1 \mathrm{~h}$ at different concentrations of antioxidant solutions. The budding sites were closed with plastic tape. The seedlings were kept in a greenhouse at a temperature of about $26^{\circ} \mathrm{C}$ per day and about $23{ }^{\circ} \mathrm{C}$ per night and relative humidity of at least $70 \%$. A skilled worker was employed to perform the budding. Although successful buddings were evaluated every week, the final percentage of budding success was determined one month after budding. In addition, measurements of traits such as shoot length, shoot diameter, number of scion leaves, concentrations of chlorophyll a and $b$, and total chlorophylls were undertaken three months after budding. The amount of photosynthetic pigments (chlorophyll a, b, and total) was determined according to the method of Lichtenthaler (1987). The pigment extract was measured versus a blank of $80 \%(\mathrm{~V} / \mathrm{V})$ acetone at wavelengths of 646.8 and $663.2 \mathrm{~nm}$ for chlorophyll assays.

Data was analyzed using SAS software. To normalize the distribution, data related to the percentage of budding success were converted as Arc Sin and the remaining data were converted using log $(x+10)$. The comparison of means was done by Tukey's method at 5\% probability level.

\section{RESULTS}

The three genotypes studied showed significant differences in all of the indices, except in the content of chlorophylls. However, no interaction was found between cultivars and antioxidant concentrations (Table 1). The highest percentage of budding success was found in Z60 (82.75\%), while in B21 and Z30, the effectiveness was slightly lower -81.32 and $78.46 \%$ (Fig. 1A). 
Table 1. The ANOVA results of the tested characters that are important in patch budding

\begin{tabular}{|c|c|c|c|c|c|c|c|c|}
\hline \multirow[b]{2}{*}{$\begin{array}{c}\text { Source } \\
\text { of variation }\end{array}$} & \multirow[b]{2}{*}{ df } & \multicolumn{7}{|c|}{ Mean square } \\
\hline & & $\begin{array}{c}\text { budding } \\
\text { success } \\
(\%)\end{array}$ & $\begin{array}{l}\text { length of } \\
\text { shoot } \\
(\mathrm{cm})\end{array}$ & $\begin{array}{l}\text { diameter } \\
\text { of scion } \\
(\mathrm{mm})\end{array}$ & $\begin{array}{l}\text { number } \\
\text { of leaves }\end{array}$ & $\begin{array}{l}\text { chlorophyll a } \\
\quad\left(\mathrm{mg} \cdot \mathrm{g}^{-1}\right)\end{array}$ & $\begin{array}{l}\text { chlorophyll b } \\
\left(\mathrm{mg} \cdot \mathrm{g}^{-1}\right)\end{array}$ & $\begin{array}{c}\text { total } \\
\text { chlorophyll } \\
\left(\mathrm{mg} \cdot \mathrm{g}^{-1}\right)\end{array}$ \\
\hline Model & 20 & $207.00 * *$ & $82.80 * *$ & $5.88 * *$ & $0.84 * *$ & $25.30 * *$ & $10.73 * *$ & $67.75 * *$ \\
\hline Cultivar & 2 & $233.33^{*}$ & $801.73 * *$ & $54.34 * *$ & $3.82 * *$ & $0.77 \mathrm{~ns}$ & $0.37 \mathrm{~ns}$ & $1.96 \mathrm{~ns}$ \\
\hline $\begin{array}{l}\text { Antioxidant } \\
\text { solution }\end{array}$ & 6 & $612.24 * *$ & $8.66^{* *}$ & $1.48 * *$ & $1.54 * *$ & $82.96 * *$ & $35.56 * *$ & $223.98 * *$ \\
\hline $\begin{array}{l}\text { Cultivar } \times \text { an- } \\
\text { tioxidant so- } \\
\text { lution }\end{array}$ & 12 & $0.02 \mathrm{~ns}$ & $0.05 \mathrm{~ns}$ & $0.01 \mathrm{~ns}$ & $0.01 \mathrm{~ns}$ & $0.56 \mathrm{~ns}$ & $0.05 \mathrm{~ns}$ & $0.60 \mathrm{~ns}$ \\
\hline Error & 126 & 54.98 & 0.55 & 0.08 & 0.07 & 0.43 & 0.25 & 0.69 \\
\hline $\mathrm{Cv}(\%)$ & & 9.17 & 5.11 & 5.76 & 6.01 & 4.93 & 7.74 & 4.18 \\
\hline
\end{tabular}

* Significance levels at 5\%. ** Significance levels at $1 \%$.

ANOVA, analysis of variance; ns, not significant.
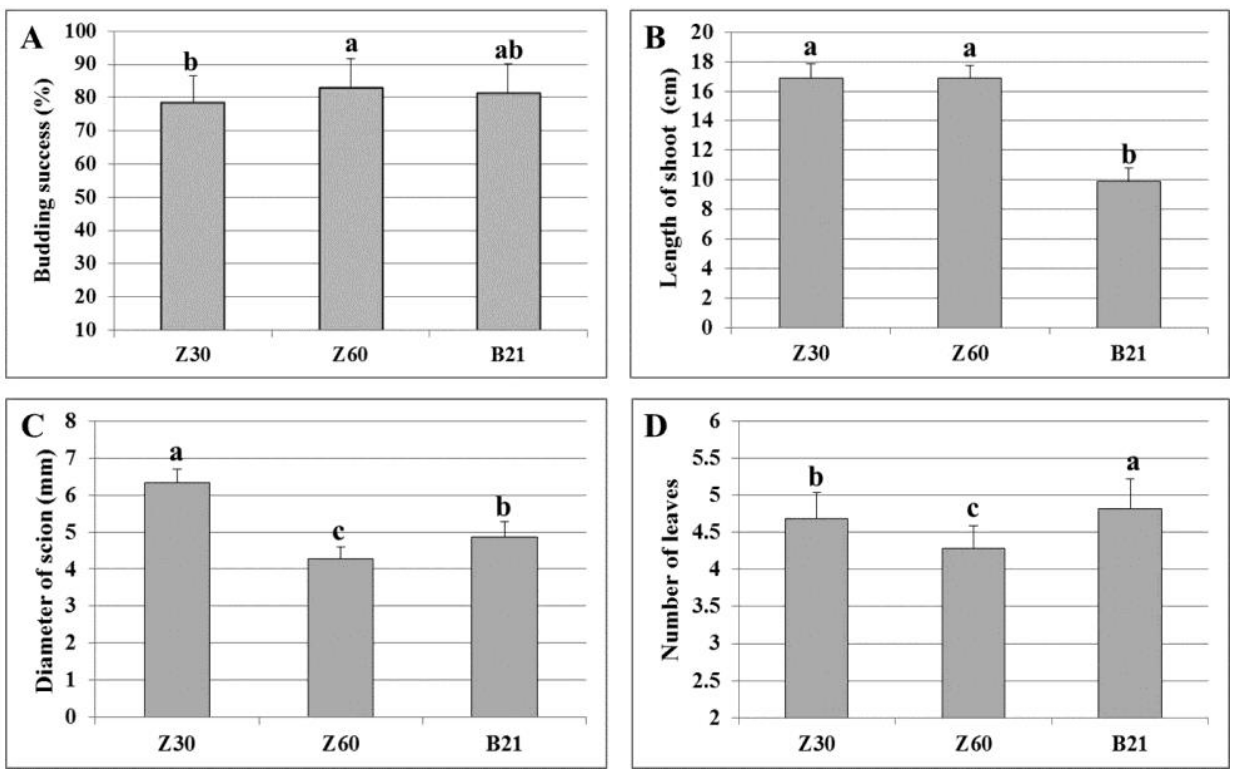

Fig. 1. Effect of cultivar on (A) the percentage of budding success, (B) length of shoot, (C) diameter of scion, and )D( number of leaves. Bars with different letters are significantly $\geq$ different from each other at P0.05 )Tukey's test $( \pm$ values.

The mean comparison of three genotypes showed that the maximum shoot length of scion was 16.89 and $16.87 \mathrm{~cm}$ in $\mathrm{Z60}$ and Z30, respectively, while $10.0 \mathrm{~cm}$ in B21 (Fig. 1B). The average scion diameter was the highest in $\mathrm{Z} 30(6.33 \mathrm{~mm})$, followed by B21 $(4.87 \mathrm{~mm})$ and Z60 $(4.28 \mathrm{~mm})$ (Fig. 1C). The number of leaves was from 4.82 to $4.28 \mathrm{~mm}$ (Fig. 1D).

The antioxidant solutions significantly affected all the indices studied (Table 1) here, although differences were not always big (Fig. 2). The highest percentage of budding success was $86.66 \%$ in the treatment of $3 \mathrm{~g} \cdot \mathrm{dm}^{-3}$ of ascorbic acid, but no significant difference was observed with $4 \mathrm{~g} \cdot \mathrm{dm}^{-3}$ of ascorbic acid and 3 and $4 \mathrm{~g} \cdot \mathrm{dm}^{-3}$ of PVP treatments. Control treatment showed the lowest percentage of budding success (72.38\%) (Fig. 2A).

Comparison of means showed that the maximum shoot length $(15.45 \mathrm{~cm})$ was related to $3 \mathrm{~g} \cdot \mathrm{dm}^{-3}$ of ascorbic acid, which showed significant 
difference with all antioxidant treatments other than treatment of $4 \mathrm{~g} \cdot \mathrm{dm}^{-3}$ of PVP (Fig. 2B).

All antioxidants increased the average scion diameters, and the highest increase was in the treatment of $4 \mathrm{~g} \cdot \mathrm{dm}^{-3}$ of ascorbic acid (Fig. 2C). The same trend was recorded in number of leaves (Fig. 2D). Antioxidant solutions significantly affected the content of chlorophylls (Table 1). The highest content of chlorophylls in leaves was found in scions treated with 3 and $4 \mathrm{mg} \cdot \mathrm{dm}^{-3}$ of ascorbic acid (Fig. 3).
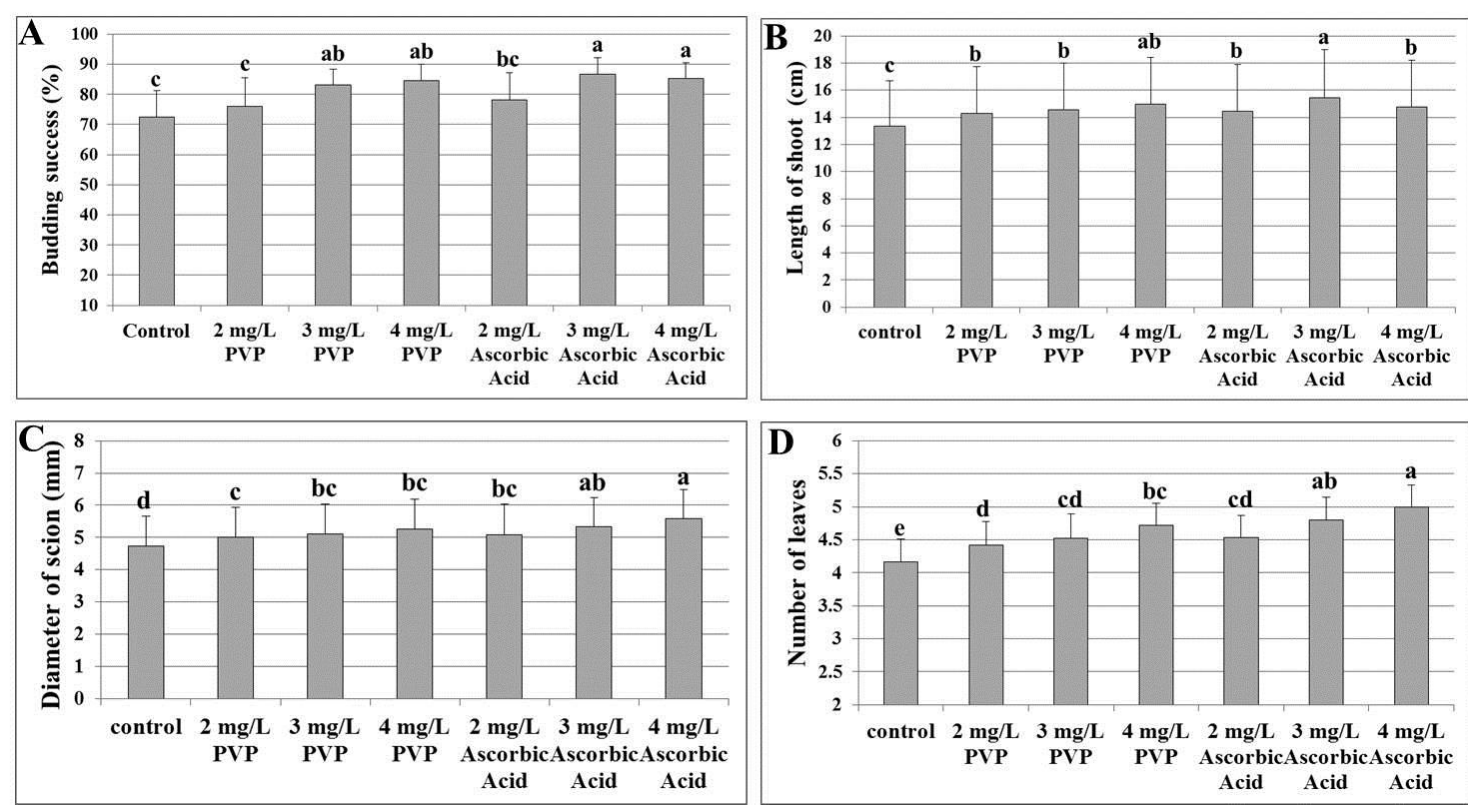

Fig. 2. Effect of antioxidant treatments on (A) the percentage of budding success, (B) length of shoot, )C (diameter of scion, and )D (number of leaves. Bars with different letters are significantly different from each other at $\mathrm{P}$ $\geq 0.05)$ Tukey's test $( \pm$ SE values.

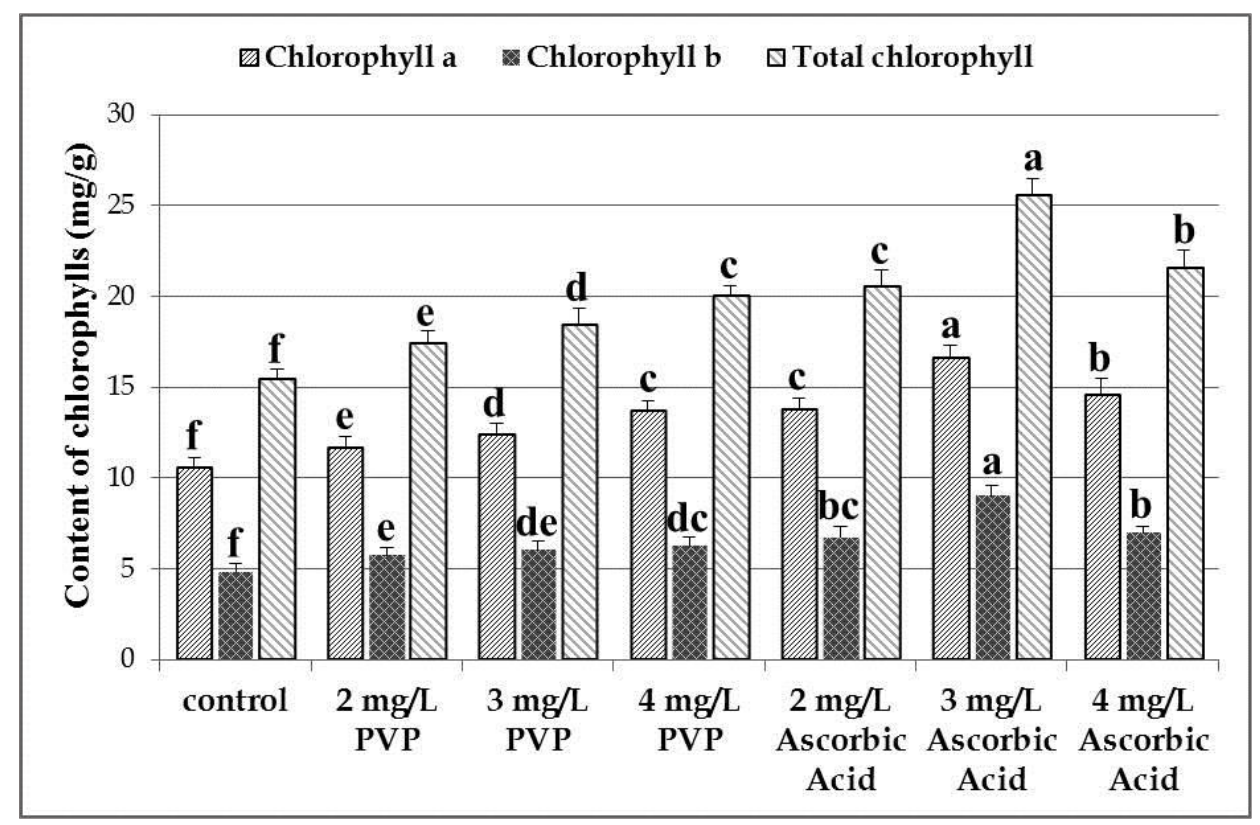

Fig. 3. Effect of antioxidant treatments on chlorophylls a and b and total chlorophyll in scion leaves. Bars with different letters are significantly different from each other at $\mathrm{P} \leq 0.05)$ Tukey's test $( \pm \mathrm{SE}$ values 


\section{DISCUSSION}

The effectiveness of budding in walnut depends on genotype (Stanisavljevic \& Mitrovic 1997; Vahdati \& Zareie 2005; Suk-In et al. 2005; Dehghan et al. 2009; Paunović et al. 2012). In Soleimani et al. (2008) study on hypocotyl grafting of walnut, the least percentage of budding success was found in Z30 genotype.

According to Rezaee and Vahdati (2008), the physiological conditions of the scion at the time of budding also influence the budding success. Various genotypes of walnut differ in terms of water content in tissues, soluble sugars, starch, carbon-tonitrogen ratio, phenolic compounds, and hormones, which can influence budding success and subsequent growth of the scions (Stanisavljevic \& $\mathrm{Mi}-$ trovic 1997; Rongting \& Pinghai 1993; 1990). Some researchers have attributed the weakness of the budding success in walnut to the high concentration of phenolic compounds in the tissues and the oxidation of these compounds at the site of the wound resulting from the graft (Pinghai \& Rongting 1993). It seems that in Z60 genotype, which had the highest budding success, a lower concentration of phenolic substances or higher concentration of antioxidant substances could be responsible for this result.

The use of antioxidant solutions has been reported as beneficial for budding success of soursop and walnut plants (Alzate et al. 2002; Zakinthinos $\&$ Rouskas 1997). Aminzadeh et al. (2013) investigated the effect of antioxidant solutions on walnut micro-grafting and showed that the immersion of scions in the PVP solution minimizes the time required for graft-take. In addition, the effect of various antioxidants on reducing the oxidation of phenolic substances in micro-grafting of the soursop plant (Annona muricata) was proved (Alzate et al. 2002). In this report, ascorbic acid and PVP stimulated the growth of the scions.

Walnuts have a significant amount of phenolic materials, especially juglon (Aminzadeh et al. 2013), content of which increases from June to midsummer. By wounding tissues in grafting or budding, these materials are significantly secreted at the site of the wound which can prevent graft-take (Rongting \& Pinghai 1993; Rezaee et al. 2008). The movement of auxins and cytokinins, which are important for the growth and differentiation of cells and vascular tissue, is stopped by phenols (Usenik \& S tampar 2000). In addition, phenolic acids inhibit the plant growth and enhance the oxidative degradation of IAA (Mng'omba et al. 2008). In this study, all the growth indices increased significantly in comparison to control treatment using scions immersion in antioxidant solutions; this could result in decrease of the releasing of phenolic materials. In tissue culture conditions, antioxidant materials are used to micropropagate plants with high phenolic content in order to reduce the secretion of these substances and prevent the browning of the medium and explants (Thomas 2008): but the use of antioxidants for the propagation of plants through graft is not common, and there are only a few reports on this topic.

\section{CONCLUSIONS}

The results of this study indicate that immersion of scions in PVP or ascorbic acid antioxidant solutions before grafting can increase significantly the percentage of budding success and subsequent growth of walnut scions. Consequently, these lowcost materials are recommended for the use in budding.

\section{Acknowledgments}

This work was supported by the Arak University. We thank Mr. Momivand for doing the buddings.

\section{REFERENCES}

Aloni R. 2001. Foliar and axial aspects of vascular differentiation: hypotheses and evidence. Journal of Plant Growth Regulation 20: 22-34. DOI: 10.1007/s003440010001.

Alzate A., Royero N., Nuñez V., Cabra J., Tohme J., Mejía-Jiménez A. 2002. Optimization of the in vitro propagation methodology of selected clones of soursop (Annona muricata L.) and evaluation of the compatibility of different scion and rootstock combinations for in vitro micrografting. Annual Report CIAT, Project SB-2, Assessing and utilizing of agrobiodiversity through biotechnology, pp. 318-323.

Aminzadeh F., Fattahi Moghaddam M.R., Ebadi A., Hasani D., Blanian H. 2013. Effect of grafting time, 
antioxidant and plant growth regulators on minigrafting in walnut (Juglans regia $\mathrm{L}$.). Seed and Plant Production Journal 29(2): 269-282. [in Persian with English abstract]

Azimi M., Özkaya M.T., Çölgecen H., Büyükkartal H.N. 2016. Analysis of phenolic compounds for determination of cambium differentiation and tracheal elements in olive graft combinations. Journal of Experimental Biology and Agricultural Sciences 4: 714-720. DOI: 10.18006/2016.4(VIS).714.720.

Dehghan B., Vahdati K., Rezaee R., Hassani D. 2009. Persian walnut (Juglans regia L.) grafting as influenced by different bench grafting methods and scion cultivars. Journal of Applied Horticulture 11(1): 56-58.

Errea P., Felipe A., Herrero M. 1994a. Graft establishment between compatible and incompatible Prunus spp. Journal of Experimental Botany 45: 393-401. DOI: $10.1093 / \mathrm{jxb} / 45.3 .393$.

Errea P., Treutter D., Feucht W. 1994b. Characterization of flavanol type-polyphenols in apricot cultivar and rootstocks. Advances in Horticultural Science 3: 165-169.

Errea P., Garay L., Marín J.A. 2001. Early detection of graft incompatibility in apricot (Prunus armeniaca) using in vitro techniques. Physiologia Plantarum 112: 135141. DOI: 10.1034/j.1399-3054.2001.1120118.x.

FAOSTAT 2014. http://www.faostat.fao.org.

Godeanu I., Baciu A., Achim G.H., Cosmulescu S. 2004. Achievements and perspectives in creating rootstocks and in the technology for obtaining grafted walnut trees in Romania. Acta Horticulturae 658: 479-486. DOI: 10.17660/ActaHortic.2004.658.71.

Karadeniz T. 2003. Flavan content of annual shoots affects graft-take success in walnut (Juglans regia). South African Journal of Botany 69(3): 292-294. DOI: 10.1016/S0254-6299(15)30316-1.

Karadeniz T. 2005. Relationships between graft success and climatic values in walnut (Juglans regia L.). Journal of Central European Agriculture 6: 631-634.

Kasmi M., Rama P., Hodaj B., Kukali E., Rabeta A. 2013. Budding of walnut (Juglans regia L.). Albanian Journal of Agricultural Sciences 12(3): 465-469.

Lichtenthaler H.K. 1987. Chlorophylls and carotenoids: Pigments of photosynthetic biomemberanes. Methods in Enzymology 148: 350-382. DOI: 10.1016/0076-6879(87)48036-1.

Lockard R.G., Schneider G.W. 1981. Stock and scion growth relationships and the dwarfing mechanism in apple. Horticultural Reviews 3: 315-375. DOI: 10.1002/9781118060766.ch7.
Mng'omba S.A., du Toit E.S., Akinnifesi. F.K. 2008. The relationship between graft incompatibility and phenols in Uapaca kirkiana Müell Arg. Scientia Horticulturae 117: 212-218. DOI: 10.1016/j.scienta.2008.03.031.

Paunović S.M., Miletić R., Mitrović M., Janković D. 2012. Graft-take success in walnut under controlled conditions and plant development in the nursery. Notulae Botanicae Horti Agrobotanici Cluj-Napoca 40(2): 170-176. DOI: 10.15835/nbha4028145.

Pinghai D., Rongting X. 1993. Effect of phenols on the survival of walnut grafting. Acta Horticulturae 311: 134-140. DOI: 10.17660/ActaHortic.1993.311.18.

Reddy C.V., Melanta K.R. 1989. Effect of different scion varieties on the success of softwood grafting of mango in relation to phenols content. Mysore Journal of Agricultural Sciences 23: 341-343.

Rezaee R., Vahdati K. 2008. Introducing a simple and efficient procedure for topworking Persian walnut trees. Journal of the American Pomological Society 62: 21-26.

Rezaee R., Vahdati K., Grigoorian V., Valizadeh M. 2008. Walnut grafting success and bleeding rate as affected by different grafting methods and seedling vigour. Journal of Horticultural Science and Biotechnology 83: 94-99. DOI: 10.1080/14620316.2008.11512352.

Rongting X., Pinghai D. 1990. Theory and practice of walnut grafting. Acta Horticulturae 284: 69-90. DOI: 10.17660/ActaHortic.1990.284.10.

Rongting X., Pinghai D. 1993. A study on the uniting process of walnut grafting and the factors affecting. Acta Horticulturae 311: 160-170. DOI: 10.17660/ActaHortic.1993.311.21.

Soleimani A., Rabiei V., Hassani D., Amiri M.E. 2008. Effects of rootstock and cultivar on propagation of Persian walnut (Juglans regia L.) using hypocotyle grafting. Seed and Plant Production Journal 25(2): 93-101. [in Persian with English abstract]

Stanisavljevic M., Mitrovic M. 1997. Effect of variety on successful grafting and development of nursery trees of walnut (Juglans regia L.). Acta Horticulturae 442: 281-284. DOI: 10.17660/ActaHortic.1997.442.42.

Suk-In H., Moon-Ho L., Yong-Seok J. 2005. Study on the new vegetative propagation method 'epicotyl grafting' in walnut trees (Juglans spp.). Acta Horticulturae 705: 371-377. DOI: 10.17660/ActaHortic.2005.705.52.

Thomas T.D. 2008. The role of activated charcoal in plant tissue culture. Biotechnology Advances 26: 618-631. DOI: 10.1016/j.biotechadv.2008.08.003. 
Treutter D., Feucht W. 1988. Accumulation of the flavonoid prunin in Prunus avium/P. cerasus grafts and its possible involvement in the process of incompatibility. Acta Horticulturae 227: 74-78. DOI: 10.17660/ActaHortic.1988.227.6.

Usenik V., S`tampar F. 2000. Influence of various rootstocks for cherries on p-coumaric acid, genistein and prunin content and their involvement in the incompatibility process. Gartenbauwissenschaft 65 : 245-250.
Vahdati K., Zareie N. 2005. Evaluation of side-stub and hypocotyle grafting efficiency for walnut propagation in Iran. Acta Horticulturae 705: 347-351. DOI: 10.17660/ActaHortic.2005.705.47.

Zakinthinos G., Rouskas D. 1997. Specific treatments on walnut grafting improvement. Acta Horticulturae 442: 285-290. DOI: 10.17660/ActaHortic.1997.442.43. 